\title{
Measuring Spatial Justice Indices in the Traditional Islamic Cities by Using GIS, An-Najaf Holy City, Iraq, A Case Study
}

\author{
Tuqa R. Alrobaee \\ Regional Planning Department, Faculty of Physical Planning, University of Kufa, Najaf, Iraq, \\ tuqar.alrobaee@uokufa.edu.iq
}

\begin{abstract}
Iraq includes several traditional Islamic cities, and they share many spatial and social characteristics. A question has often been raised about these cities' ability to achieve spatial justice for their current residents. Therefore, the research aims to answer this question by following a specific methodology based on the derivation of factors and indices of spatial justice through previous literature, then measuring the indices derived in the ancient Najaf city as an example of traditional Islamic cities. The research found that there are five main factors for spatial justice, which are: spatial diversity, spatial connectivity, spatial resilience, spatial security, and spatial empowerment, which in turn are divided into ten indices. These indices were measured in Najaf city. It became clear that the mixed land use index, spatial connectivity indices, and spatial security indices were well achieved, while the mixed residential patterns and spatial empowerment indices did not achieve well. As for spatial resilience, changes occurred in the land uses. However, these changes were not the result of social and cultural changes or according to the city residents' needs. Instead, they occurred due to economic changes that primarily serve the visitors and arrivals to the city.
\end{abstract}

Keywords: spatial justice, spatial diversity, spatial connectivity, Spatial resilience, spatial security, and spatial empowerment.

Received: February $1^{\text {st }}, 2021$ / Accepted:March $4^{\text {th }}, 2021$ / Online: March $6^{\text {th }}, 2021$

\section{Introduction}

The concept of justice is taken from the word "equity" which means putting everything in its place, and it is also one of the main concepts of sustainable urban development (Mortezavi, 2019). Webster defines justice as a legal system in which foundations and laws are amended to correct the system's failure to define fair and just cases (Morrill, 2015). The concept of urban justice is one of the concepts closely related to the concept of justice.

One of the most famous theories in urban justice is the "Fair city theory" advocated by Susan Fainstein in the late nineties of the last century, in which it supported social equality and tried to take advantage of the values found in the philosophical concept of justice, the values, and standards effective in producing and developing a good city (Fainstein, 2000). A fair city needs a progressive vision and an innovative approach to entrepreneurship, raising economic value and welfare. Besides, there must be a plan to empower the poor and deprived of their rights while ensuring the middle social class (Fainstein, 2000). Fainstein has concluded that 
there are three governing principles of justice: fairness, democracy, and diversity (Fainstein, 2014).

Two different views emerged in the concept of urban justice that polarized debate and controversy, were based on the works of many famous justice philosophers such as (John Rawls, Iris Marion Young). The first approach focuses on issues of redistribution. It is represented in asking questions about spatial or sociospatial distributions and how to achieve an equal geographical distribution of the community's needs and desires. Justice is evaluated based on the results. In contrast, the second approach focuses on the decisionmaking process. It raises issues related to social practices and issues of space representation and regional identity; it allows, for example, to focus on minorities to understand their spatial practices. Questions are raised about space representations, whether spatial or non-spatial and questions about identity and experience because justice is defined according to this approach as an ongoing process (Rafieian \& Alizadeh, 2017).

The urban concept of justice can be summed up in two aspects: social justice and spatial justice (Feng \& Timmermans, 2014). Spatial justice will be addressed in this study. Urban planning is one of the main means of achieving spatial justice, and that achieving social justice depends on achieving greater spatial justice. This idea has dominated many circles and contexts until many specialists saw that urban planning and spatial justice research are equivalent (Mabin, 2013). Urban space is also a fundamental dimension in human society, reflecting social realities and affecting social relations. That social justice flows into the urban space, in which justice and injustice appear (GHaedrahmati, Khademalhoosini, \& Tahmasebi, 2018).

Formative concepts of spatial justice are centered around distributive justice concepts to achieve fairness and give it a central place to procedural aspects of justice, aiming to empower people (Kay, 2005). Therefore, urban planners' most important task in this field is to achieve equal opportunities through which different groups and segments of society are guaranteed access to urban services (Achmani et al., 2020).

Spatial justice is defined as "the appropriate distribution of services, resources, and activities without discrimination between citizens and regions" (Rafieian \& Alizadeh, 2017). It also indicates access to public goods, essential services, cultural goods, economic opportunities, and healthy environments through equitable, comprehensive, and effective spatial planning, design, and management of urban and rural spaces and resources (Breheny, 1996). Spatial justice has also been described and defined in urban planning by four main factors: the right to the city, spatial balance, social mobilization, and empowerment (Mirgholami et al., 2018). It can be said that spatial justice prevails when there is easy access to services in different areas, which is also called horizontal justice (Kay, 2005).

A group of researchers believes that there are three interventions with associated indices that would be a reason to prevent spatial inequality, namely: land use, access, and redistribution (Achmani et al., 2020). It follows that the built environment that contains public services and provides walking and cycling will affect accessibility. This is clearly reflected in the aspects of daily life that residents and users need to achieve equitable access (Burton, 2000). Equitable access includes access to educational and other public services (Breheny, 1996), as well as equitable distribution of green and urban spaces and their accessibility (Mahmoudi et al., 2019).

The functional mix between land uses would enhance the quality of services and housing to ensure the reduction of spatial inequality (Achmani et al., 2020). The importance of providing a mixture of housing patterns to meet all people's housing needs has also emerged (Uwayezu \& De Vries, 2018). Also, the importance of obtaining affordable housing, especially for the poor and low-income groups, and ensuring easy access to it (Rafieian \& Alizadeh, 2017).

Access to public transport is an important index in promoting spatial justice, as access to public transport is the right of every person. Public transport must provide a minimum level of accessibility, and public transport must be useful and beneficial to the poor and low-income groups and the need to assess the equitable distribution of public transport stations spatially (Adli et al., 2019). 
Spatial connectivity connects both people and places and provides the necessary communication and opportunities for social well-being. The fair urban environment must reduce material and emotional vulnerability and well-being threats to provide a sense of security and safety, in addition to the necessity of spatial and social conditions that support the elimination of danger, exclusion, and harm (Griffin, 2019). Spatial resiliencies are factors of spatial justice, as it refers to adaptation over time, which enhances the interactions between supply and demand for space over time (Mirgholami et al., 2018).

This research deals with the concept of spatial justice, deriving its indices and measuring them in the traditional Islamic An-Najaf city. Indices are measured using several mathematical methods, and spatial maps are created using geographic information systems. The research aims to know the study area's reality and the percentage of achieving spatial justice in it. This helps suggest a set of solutions to develop the study area, and start in achieving spatial justice in other Iraqi cities.

\section{Materials and Methods}

The research follows a specific methodology represented in finding the main factors of spatial justice. The research proceeds to derive the indices then measure them in the study area. The study methodology flowchart was shown in Figure 1.

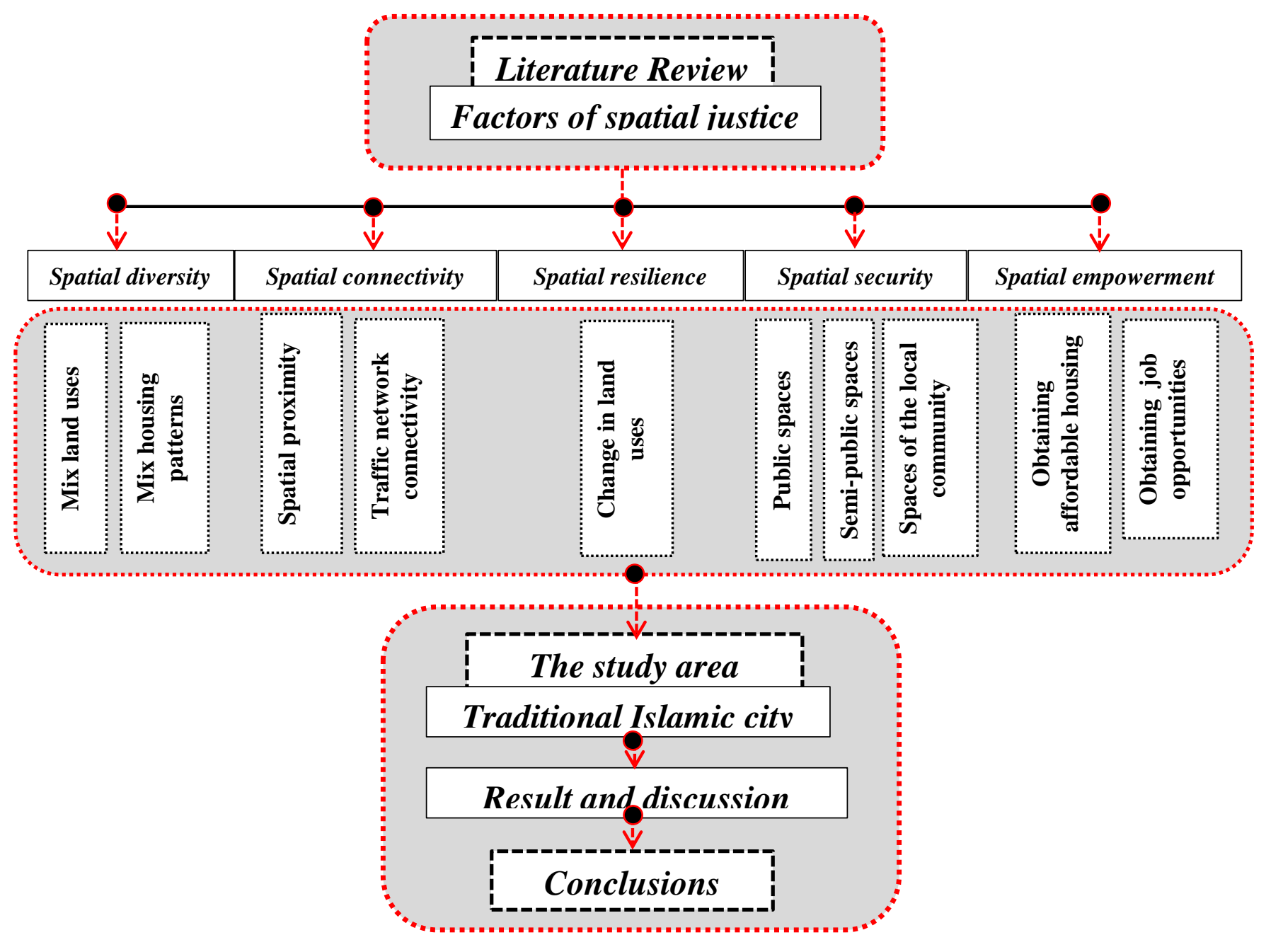

Figure 1. Research Methodology 


\subsection{Study Area}

The Traditional Islamic Najaf city (Figure 2) is the basic nucleus from which the contemporaneity Najaf city was formed. It is one of the Iraqi cities located in the central Euphrates region at a distance of 160 $\mathrm{km}$ south of Baghdad's capital city, with lat. $32^{\circ} 0^{\prime} \mathrm{N}$, and long. $44^{\circ} 20^{\prime}$ E. The city gained exceptional importance due to Imam Ali ibn Abi Talib's holy shrine, the fourth caliph for the Muslims (Al-Jaberi et al., 2019). Najaf is an important scientific and cultural center in the Islamic world due to the seminary and many religious schools' existence and important historic buildings. Besides, the city consists of four neighborhood zones: Al-Mishraq, Al-Huwaish, Al-Emara, and Al-Buraq, with an area of approximately 60 hectares.

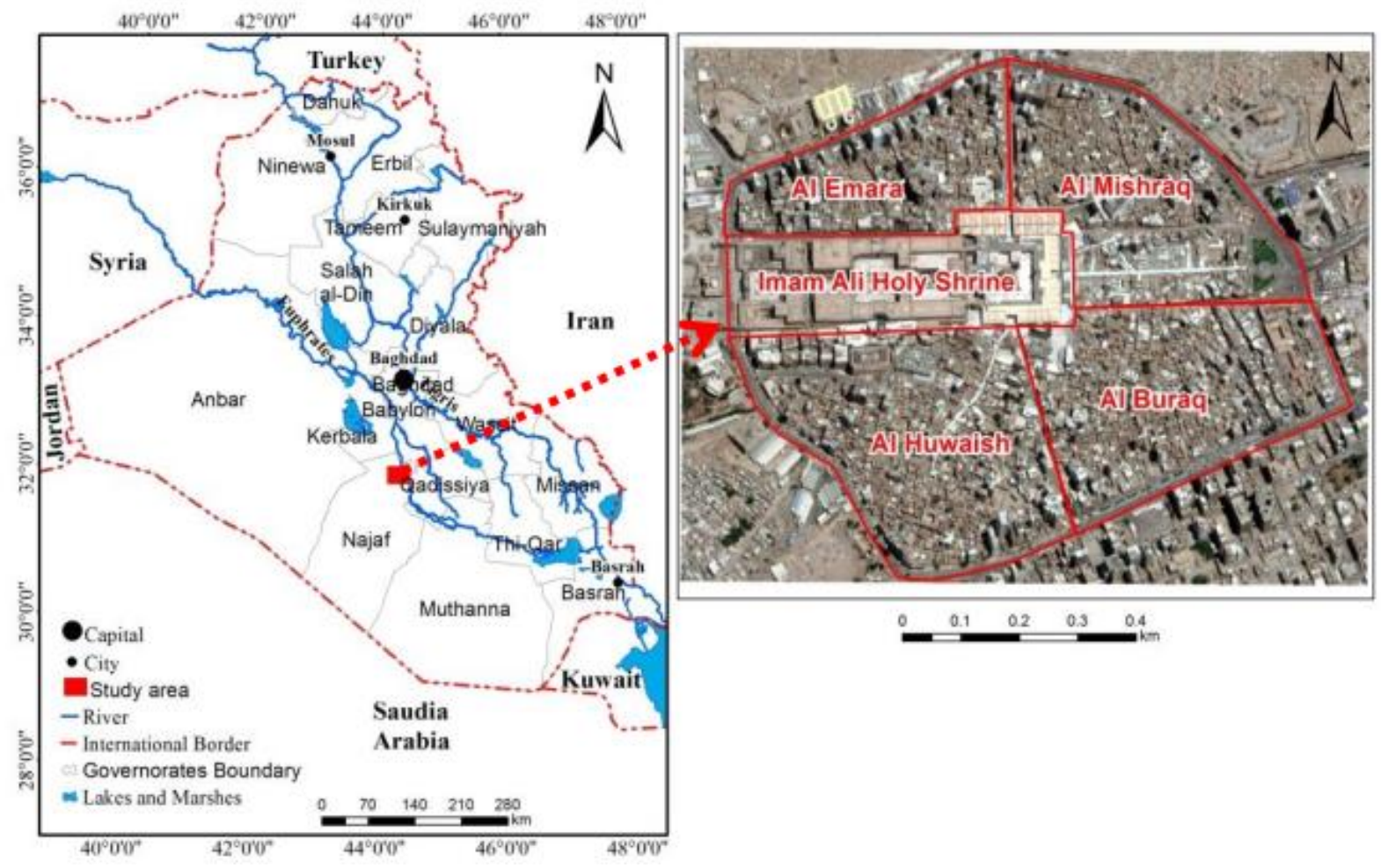

Figure 2. Location map of the study area and its neighborhoods

2.2. Spatial diversity: Includes mixed land use and mix housing patterns:

\section{- Mix land uses:}

The mixing of land uses allows for a group of uses, including residential, commercial, and industrial, to be shared in an integrated way. Mixing in uses can be measured through the Simpsons index by adopting the equation (Al-Shouk \& Al-Khfaji, 2018).

$$
\mathrm{D}_{\mathrm{i}}=1-\sum(\mathrm{n} / \mathrm{N})^{2}
$$

Where $\mathrm{n}$ represents the area of each type of land use (residential, commercial, civil, for example) in a hectare within a locality, $\mathrm{N}$ represents the total area of a locality. Di represents the resulting mixing index 
and is expressed as a value ranging from $0-1$, where the values closer to 0 mean less diversity and values closer to 1 mean high diversity. Lands designated for public streets are usually excluded.

\section{- Mix housing patterns:}

The presence of various housing patterns and the possibility of choosing and comparing them is an effective indices of satisfaction (Day, 2000). This matter provides the possibility to have a mixture of all classes of society in the urban fabric based on their different socio-economic conditions (Uwayezu \& De Vries, 2018). The lack of mixed housing options will lead to an imbalance in society and housing function (Al-Khafaji \& Al-Salam, 2018). The Entropy Index can measure it using the following formula.

$$
\mathrm{ENT}=-\left[\sum_{j=1}^{k} P^{j} \ln \left(P^{j}\right)\right] / \ln (k)
$$

Where: $(\mathrm{k})$ is the number of existing housing patterns, and (pj) is the percentage of each type within the urban area. The value of this index ranges from $0-1$, where values closer to 0 mean less diversity and values closer to 1 mean high diversity.

2.3. Spatial connectivity: Includes spatial proximity and network connectivity as follows:

\section{- Spatial proximity:}

Provides appropriate and comfortable proximity to the basic needs, facilities, and services. Several studies have determined that the acceptable walking distance that a person travels from his home to service areas is within a quarter of a mile, approximately 400 meters (Delden et al., 2008).

Access to public transportation is also an important index in achieving spatial justice because it contributes to providing access to opportunities and access to activities and services such as work, education, health, shopping, and social leisure activities. This makes it easy to participate in life. The appropriate distance between home and public transport station has been set between 400 Meters to 800 meters. In comparison, a distance of 200 meters is specified for areas where the elderly are large (Daniels \& Mulley, 2013).

- Traffic network connectivity:

Network connectivity is defined as the extent to which streets connect with a numerical density of intersections, a large number of short links, and a small number of cul-de-sacs (Alrobaee et al., 2021). It can be measured by dividing the number of real nodes by unit area, and a higher number indicates more intersections and high connectivity (Mecredy et al., 2011).

$$
\mathrm{R} / \mathrm{A} \geqslant 1
$$

$\mathrm{R}$ represents the number of real nodes in the neighborhood that do not lead to closed streets, $\mathrm{A}$ is the neighborhood area measured in hectares.

2.4. Spatial resilience: It means the ability of the public space to maintain its urban and social relevance over long periods of time, as space must be adaptable to the continuous change in the social and cultural patterns of the societies that make up the city and use its spaces (Alrobaee \& Al-Kinani, 2019). 
Spatial resilience can be measured by measuring the rate of change in land uses by surveying the historical development of land uses in the region and using previous maps of the place during a specific period that could be ten years (Delden et al., 2008).

There are many reasons for changing land use, so there is a need for this change to maintain the continuity of the self-concept in the place, enabling it to reflect the identity of the individuals who live in it (Owen, 2013).

2.5. Spatial security: Specialists from architects and urban planners discuss spatial security concerning design factors such as the nature of spaces, direction of entrances, or lighting (Nubani \& Wineman, 2005). An observation form is used to measure several descriptive indices. Spatial security indices can be summarized as follows:

- Spatial security at the level of public spaces of the city: By creating vital areas attractive to the population, where they are interconnected with public spaces to be well monitored by pedestrians, with interconnected streets and a great mix of dense uses (Force, 2003).

- Spatial security at the level of semi-public spaces in the neighborhood: These spaces are placed within an integrated structure of streets and buildings, interspersed with pedestrian and bicycle paths (Colquhoun, 2004).

- Spatial security at the level of the spaces of the local community: It is through the glazed entrances of small housing groups overlooking the space, with the use of clear paved paths for pedestrian movement, gates and fences of low height to allow visibility, as well as providing a clear scene for monitoring and natural control by families (Colquhoun, 2004).

2.6. Spatial empowerment: This is to give the person or group formal or legal authority to improve their conditions and enhance work and influence (Griffin, 2019). The following indices can summarize it:

- The possibility of obtaining an affordable housing unit: The issue of treating housing deprivation improves the living conditions of the poor and those with low incomes (Uwayezu \& De Vries, 2018), as $100 \%$ of the population has the right to obtain housing.

- Employment opportunities: the number of jobs per economically active resident can also be measured by the number of low-income jobs per economically active and qualified working population, compared to higher-income jobs (Burton, 2000).

\section{Results and Discussion}

In practical application, GIS maps (ArcGIS, 9.3 version of the ESRI company) were used. A field survey was to determine the housing patterns, the locations of public transport stations, the prices of housing units and shops, and interviewing with residents to find out the degree of security. It became clear that residential use and commercial use were the predominant uses in the city. The residential use rate was $51 \%$, and the commercial use $28 \%$ of the city's total area. When applying the Simpsons index to neighborhoods, it became clear that the value of this index in Al-Mishraq was 0.72, while in Al-Buraq it was 0.68, and in AlHuwaish the value of the index was 0.63, while in Al-Emara it reached 0.66. (see Fig 3). 


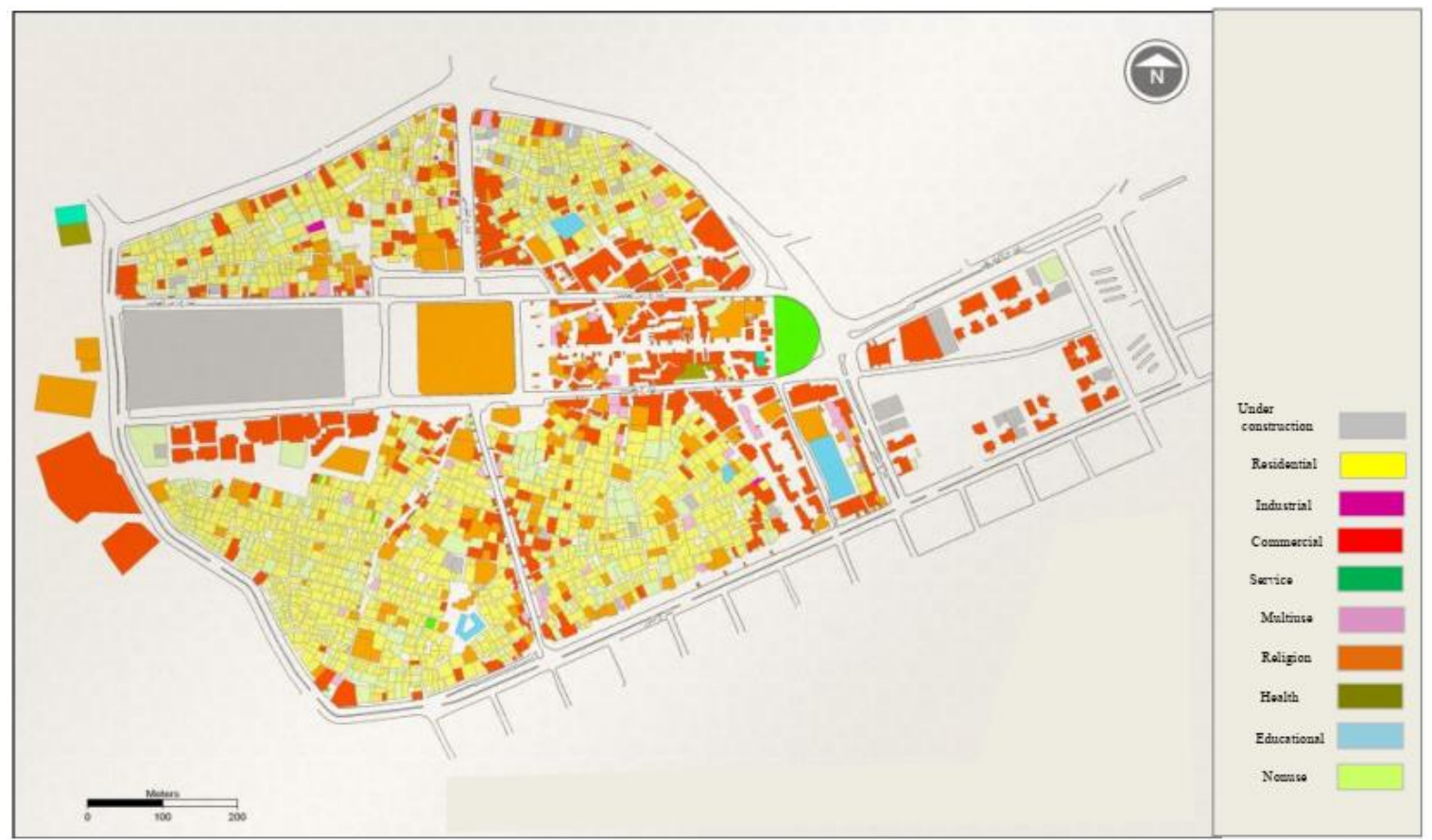

Figure 3. Mix land use in the study area (Dewan, 2011)

The traditional Najaf city is characterized by the predominance of the open-yard housing pattern, with very few and very limited numbers of the attached pattern. Therefore there is no mixed housing pattern. AlMashraq and Al-Buraq's entropy index's value was 0, in Al-Huwaish 0.01, and Al-Emara 0.02.

The traditional city Najaf is distinguished by its spatial proximity. The maximum distance towards the city center (Imam Ali's shrine) is from the Al-Huwaish neighborhood of 450 meters. There is spatial proximity within neighborhoods, as the maximum distance for services in Al-Mishraq is 380 meters, the maximum distance in accessing services in Al-Buraq is 406 meters. In comparison, in Al-Huwaish the maximum distance is 440 meters. Al-Emara is 400 meters (this is concerning health, educational, religious, and commercial services). Table 1

The spatial proximity of public transport stations was noted through the study area's field survey that there are no public transport stations formally planned or specified by the municipality. However, there are several places defined by residents in the city's vicinity, and they use them to stop and wait for public transport buses, as explained in Figure 4.

When measuring the distance to these places (unofficial public transport stations), it was found that the maximum distance in Al-Mishraq is 286 meters, while in Al-Buraq it reached 367 meters. The maximum distance in Al-Huwaish is 430 meters, and the same is the case in the Al-Emara. It reached the maximum distance for public transport 430 meters. It was also noticed that there were no green areas in the study area. Table 1.

The traditional Najaf city is characterized by its narrow and twisted alleys, as it is mainly reserved for pedestrian traffic, so it has good connectivity, as shown in Table 1. 
Table 1. Spatial connectivity indices in the study area

\begin{tabular}{cccc}
\hline neighborhoods & \multicolumn{2}{c}{ Spatial proximity } & $\begin{array}{c}\text { Traffic network } \\
\text { connectivity }\end{array}$ \\
\cline { 2 - 3 } & $\begin{array}{c}\text { maximum } \\
\text { distance for } \\
\text { services }(\mathrm{m})\end{array}$ & $\begin{array}{c}\text { maximum distance for } \\
\text { transport stations }(\mathrm{m})\end{array}$ & \\
\hline Al-Mishraq & 380 & 286 & 2.5 \\
Al-Buraq & 406 & 367 & 2 \\
Al-Huwaish & 440 & 430 & 2.1 \\
Al-Amara & 400 & 430 & 1.9 \\
\hline
\end{tabular}

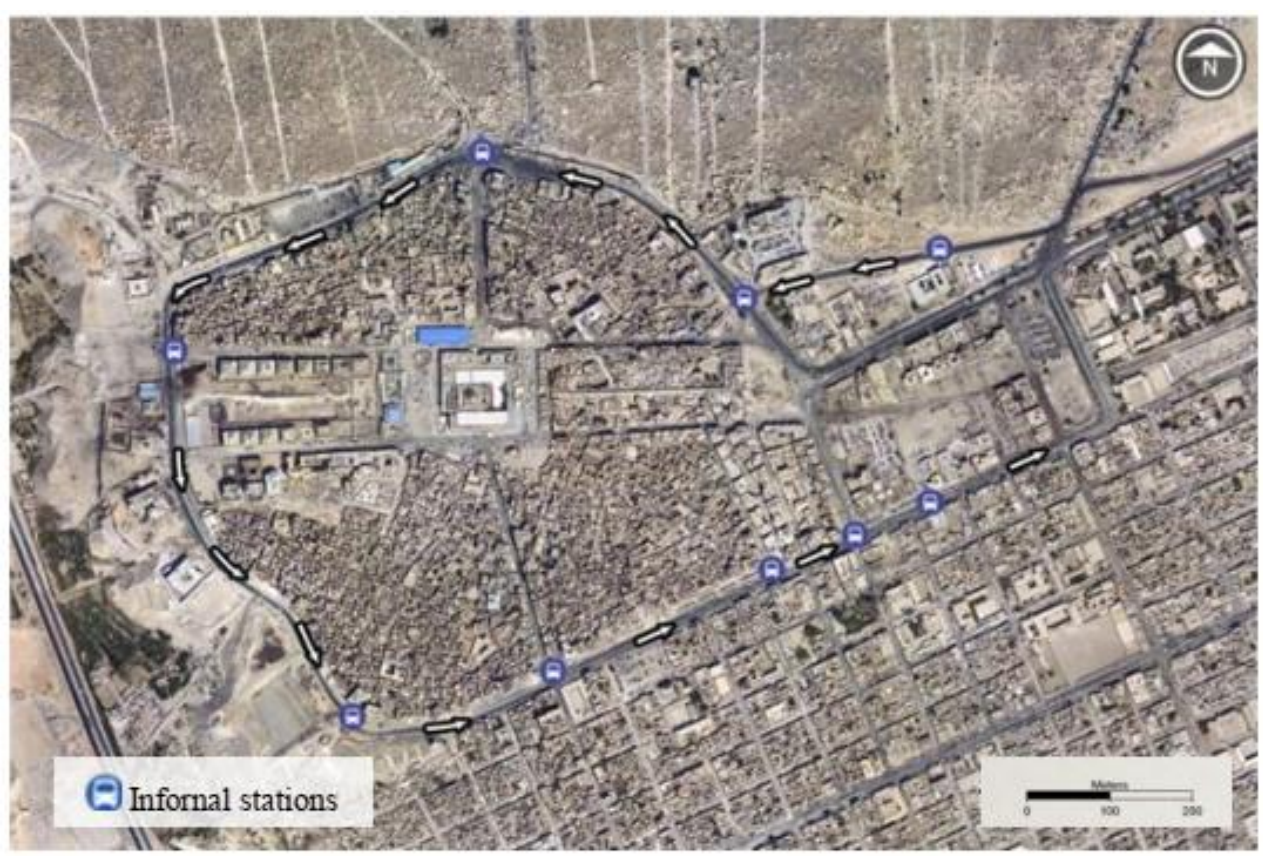

Figure 4. Informal public transport stations in the study area

Spatial resilience can be measured as presented by comparing a map of the reality of the situation and another map dating back ten years ago to find out the number of changes that occurred in it, which are associated with social and cultural changes. It became clear that changing residential buildings to hotels is the most apparent change in the study area. It was proved through a field survey that $5 \%$ of residential buildings had been transformed into hotels and commercial use during the past ten years.

The observation form and population interviews were adopted to measure the descriptive indices present in spatial security, as follows:

- Spatial security was achieved at the level of public spaces in the city, to a great extent, and by $90 \%$, as the only public space at the city level was the Imam Ali shrine's space. It was characterized by a relatively high degree of density, which creates the appropriate vitality in the place, with interconnections to this space with the surrounding area. This space contains several entrances, as it is connected to several streets from different directions. This space is characterized by a good mixed-use rate, which allows people to be present at all times (see Fig 5). 


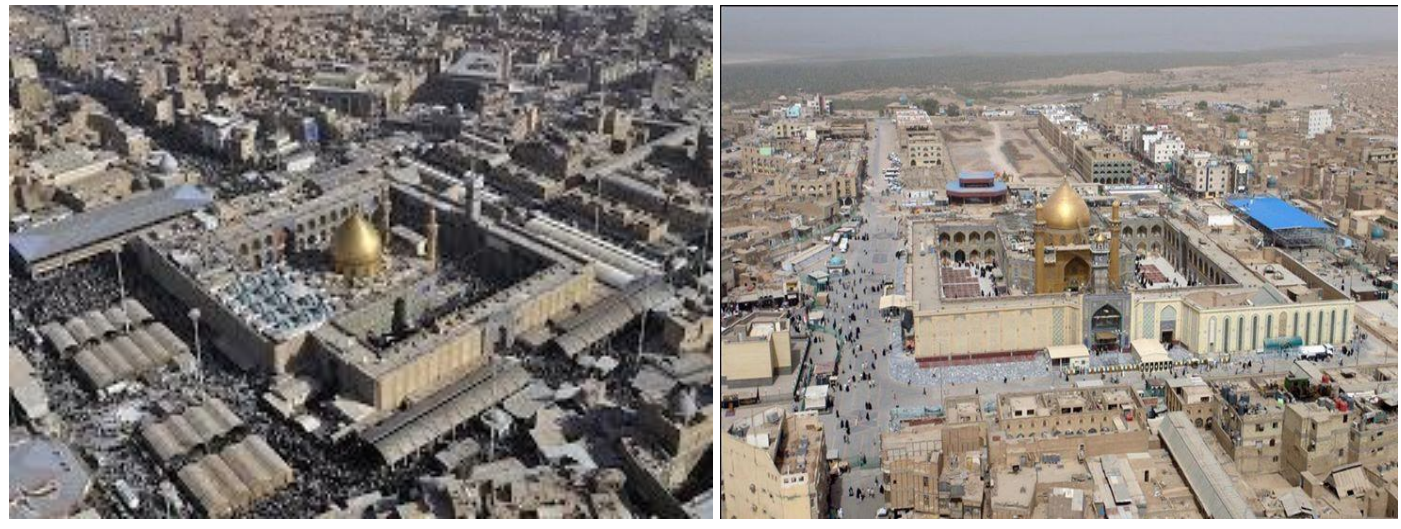

Figure 5. Aerial photos of the space surrounding the shrine of Imam Ali

- Spatial security at the level of semi-public spaces in the neighborhood: The neighborhoods in the study area are characterized by the existence of spaces subject to social control. It is located within a strong structure integrated with the streets and buildings within the neighborhood and interspersed with pedestrian paths (see Fig 6).

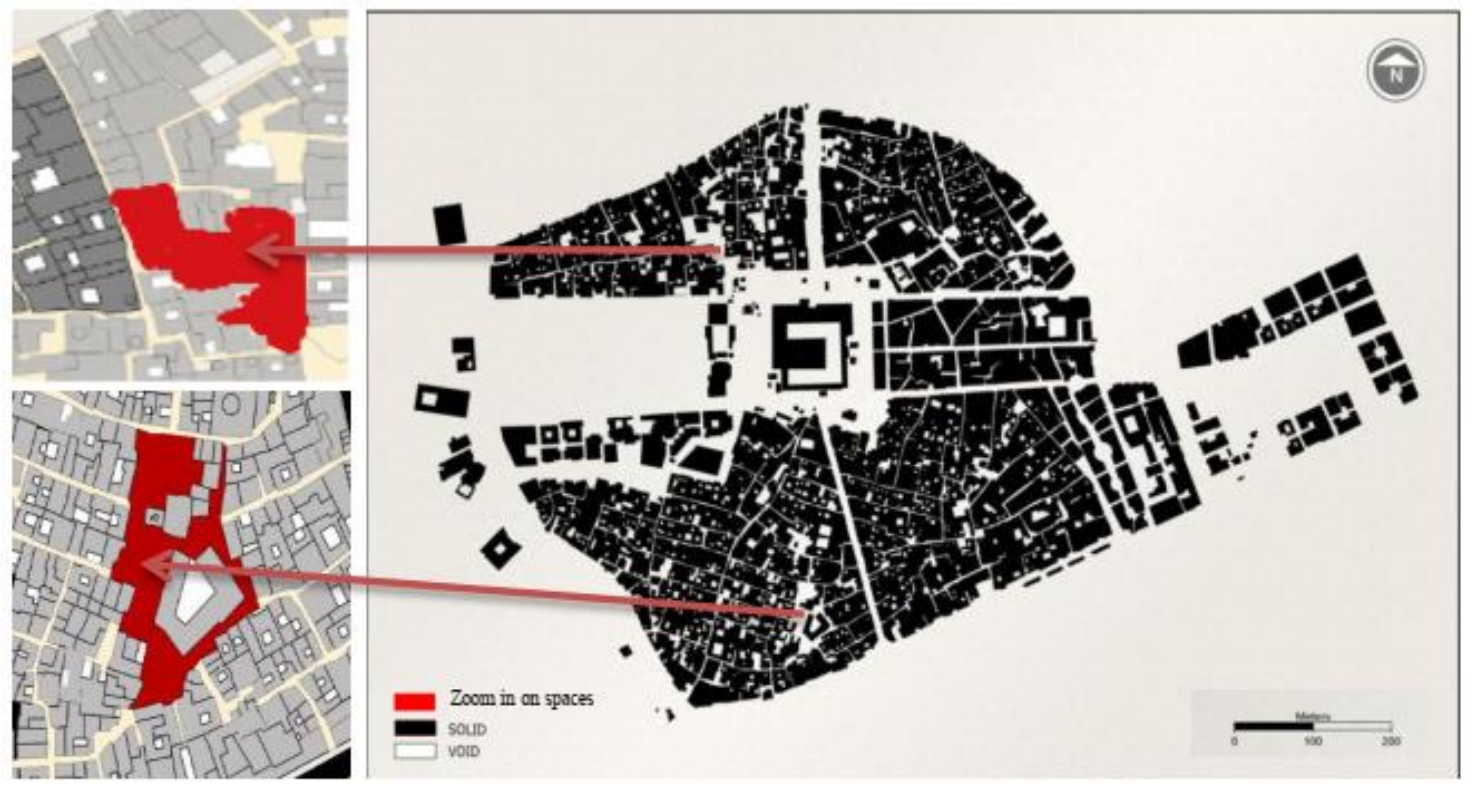

Figure 6. Semi-public spaces in the neighborhood in the study area

- Spatial security at the local community's level: These spaces are subject to social control through the system of control imposed by the home design pattern where homes on the first floor contain a number of windows overlooking the streets and spaces. In addition, the presence of clear paths for pedestrian traffic. However, it does not contain low-rise doors and fences due to the city's planning nature (Figure 7). 

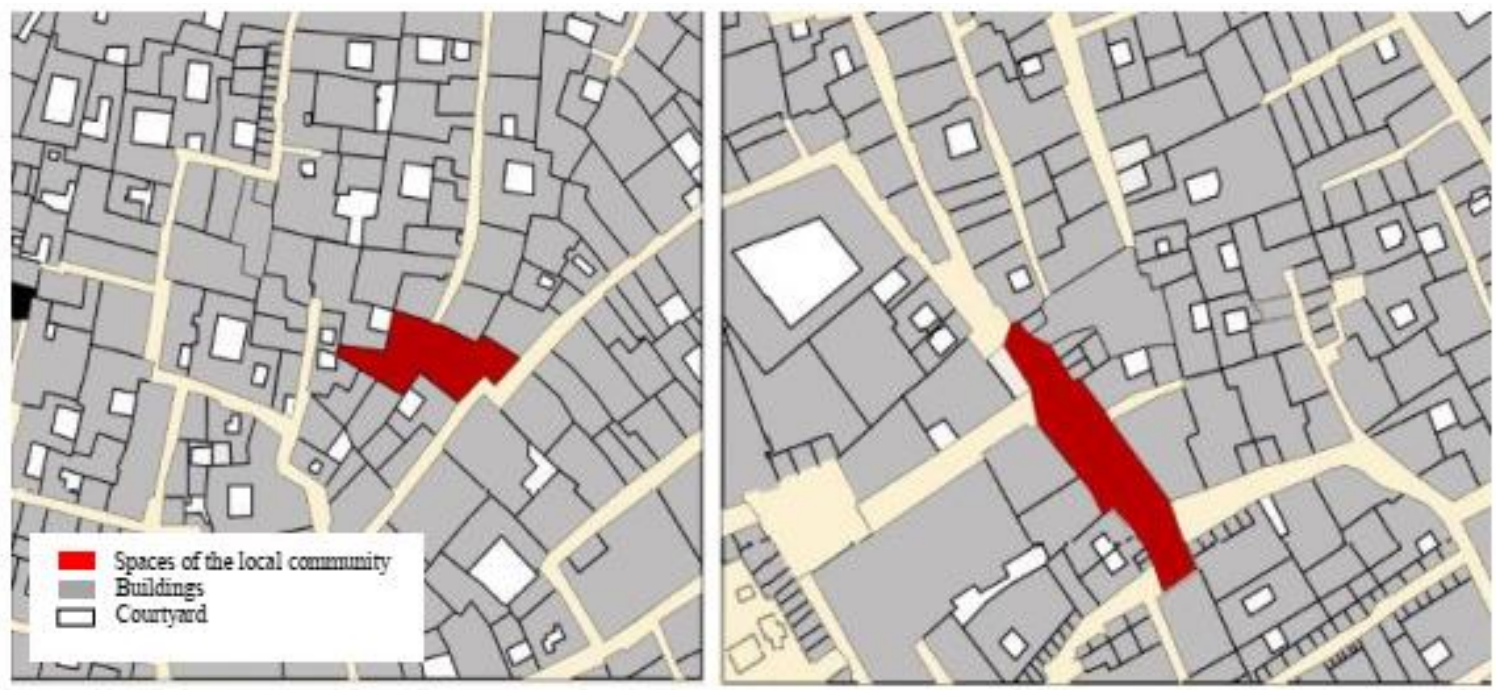

Figure 7. The spaces of the local community in the study area

- Spatial empowerment needs the government's intervention and Civil society organizations to achieve it, given his need for huge funds, coordination, and high organization between the relevant authorities.

- The possibility of obtaining affordable housing: the study area is characterized by the high prices of housing units as well as the high rental rates, due to the high value of land, as it is considered land convertible to commercial use due to its proximity to the shrine of Imam Ali, and the area gradually transformed into commercial and tourist uses.

The change in residential buildings' use to hotels is the most visible in the study area. These changes in use are accompanied by other changes related to some buildings' placement by adding other floors to them. These changes are considered one of the most important reasons for the unprecedented rise in land and real estate prices that Najaf is currently witnessing.

The rent rates for houses with an area of 120 square meters in the study area range between 15000002000000 Iraqi dinars (ID) per month, which is a very high value.

- Obtaining job opportunities: The study area is characterized by the presence of many job opportunities, especially with the shift from residential to commercial use, but many people do not own work due to the high rates of buying or renting commercial stores, as rental rates range from 500,000 ID in the narrow streets to $12,000,000$ ID in Al-Sadiq Commercial Street, and sometimes up to 25,000,000 ID in the large market of the study area (the area of the shop is 14 square meters).

Although the study area is considered a tourist destination, there is a small number of workers in the tourism sector, with their qualifications and competencies limited. Some official estimates indicate that there are more than 1000 unemployed people in the study area. The reality of the spatial justice indices in the study area can be summarized in Table 2 .

Through the previous review of the study area's reality, it is evident that there are similarities and convergence in the values extracted for the four residential neighborhoods in the study area, especially concerning indices of spatial resilience and spatial security and spatial empowerment. However, there are few differences between these neighborhoods. It relates to spatial diversity and spatial connectivity indices, which show a relative preference for the Mishraq neighborhood. It has a higher mix ratio in the land use than the rest of the neighborhoods. It contains an adequate access distance to public services and the high value of the traffic network connectivity compared to other residential neighborhoods. 
Table 2. Factors and indices of spatial justice in the study area

\begin{tabular}{|c|c|c|c|c|c|}
\hline Factors & Indices & $\begin{array}{c}\text { Measurement } \\
\text { methods }\end{array}$ & Standard & $\begin{array}{c}\text { The reality of } \\
\text { the state of the } \\
\text { study area }\end{array}$ & Notes \\
\hline \multirow{2}{*}{$\begin{array}{c}\text { Spatial } \\
\text { diversity }\end{array}$} & Mix land uses & Simpsons Index & $0-1$ & $0.63-0.72$ & $\begin{array}{c}\text { The Simpson } \\
\text { Index was } \\
\text { calculated for each } \\
\text { neighborhood } \\
\text { separately }\end{array}$ \\
\hline & $\begin{array}{l}\text { Mix housing } \\
\text { patterns }\end{array}$ & Entropy Index & $0-1$ & $0-0.02$ & $\begin{array}{c}\text { The entropy index } \\
\text { was calculated for } \\
\text { each } \\
\text { neighborhood } \\
\text { separately }\end{array}$ \\
\hline \multirow{2}{*}{$\begin{array}{c}\text { Spatial } \\
\text { connectivity }\end{array}$} & $\begin{array}{c}\text { Spatial } \\
\text { proximity }\end{array}$ & Access distance & $400-800$ & $286-440$ & $\begin{array}{c}\text { access distances } \\
\text { were calculated } \\
\text { for each } \\
\text { neighborhood } \\
\text { separately } \\
\end{array}$ \\
\hline & $\begin{array}{c}\text { Traffic network } \\
\text { connectivity }\end{array}$ & $\begin{array}{c}\text { Number of real } \\
\text { nodes/area in } \\
\text { hectares }\end{array}$ & $\geq 1$ & $1.9-2.5$ & $\begin{array}{c}\text { The connectivity } \\
\text { was calculated for } \\
\text { each } \\
\text { neighborhood } \\
\text { separately }\end{array}$ \\
\hline $\begin{array}{c}\text { Spatial } \\
\text { resilience }\end{array}$ & $\begin{array}{c}\text { Change in land } \\
\text { use }\end{array}$ & $\begin{array}{l}\text { Measure the } \\
\text { change during } \\
10 \text { years }\end{array}$ & $\begin{array}{l}\text { Identity } \\
\text { compatible } \\
\text { changes }\end{array}$ & $\begin{array}{c}5 \% \text { changes } \\
\text { from residential } \\
\text { to commercial } \\
\text { use }\end{array}$ & $\begin{array}{c}\text { It was calculated } \\
\text { through surveys } \\
\text { and field } \\
\text { observations for } \\
\text { the whole study } \\
\text { area }\end{array}$ \\
\hline Spatial security & $\begin{array}{l}\text { at the level of } \\
\text { public spaces in } \\
\text { the city } \\
\text { at the level of } \\
\text { semi-public } \\
\text { spaces in the } \\
\text { neighborhood } \\
\text { at the level of } \\
\text { the spaces of the } \\
\text { local } \\
\text { community }\end{array}$ & $\begin{array}{l}\text { Observation } \\
\text { form to } \\
\text { measure a } \\
\text { number of } \\
\text { descriptive } \\
\text { indices }\end{array}$ & $\begin{array}{l}\text { Achieve good } \\
\text { ratios of } \\
\text { descriptive } \\
\text { indices }\end{array}$ & $90 \%$ & $\begin{array}{l}\text { It was calculated } \\
\text { through the } \\
\text { observation form } \\
\text { and took random } \\
\text { samples from the } \\
\text { four } \\
\text { neighborhoods of } \\
\text { the study area }\end{array}$ \\
\hline \multirow[t]{2}{*}{$\begin{array}{c}\text { Spatial } \\
\text { empowerment }\end{array}$} & $\begin{array}{l}\text { obtaining } \\
\text { affordable } \\
\text { housing }\end{array}$ & $\begin{array}{c}\text { Rates of } \\
\text { purchase and } \\
\text { rental prices of } \\
\text { residential units } \\
\text { and their } \\
\text { comparison } \\
\text { with income } \\
\text { rate }\end{array}$ & $\begin{array}{l}\text { It should be } \\
\text { less than the } \\
\text { income rates to } \\
\text { allow for } \\
\text { purchase or rent }\end{array}$ & $\begin{array}{c}\text { Rental rates } \\
\text { range from } \\
1,500,000- \\
2,000,000 \text { Iraqi } \\
\text { dinars per } \\
\text { month for a } \\
120 \text {-square- } \\
\text { meter house }\end{array}$ & $\begin{array}{c}\text { Purchase and } \\
\text { rental rates are } \\
\text { high compared to } \\
\text { income rates and } \\
\text { were calculated } \\
\text { based on field } \\
\text { surveys }\end{array}$ \\
\hline & $\begin{array}{l}\text { Obtaining job } \\
\text { opportunities }\end{array}$ & $\begin{array}{l}\text { The number of } \\
\text { jobs per } \\
\text { economically } \\
\text { active resident }\end{array}$ & $\begin{array}{l}\text { A job (with } \\
\text { adequate } \\
\text { income) for } \\
\text { every } \\
\text { economically } \\
\text { active person }\end{array}$ & $\begin{array}{c}\text { More than } 1000 \\
\text { people are } \\
\text { unemployed }\end{array}$ & $\begin{array}{l}\text { Calculated from } \\
\text { previous statistics }\end{array}$ \\
\hline
\end{tabular}


The spatial resilience and the changes in the land use have occurred and are still occurring in the study area. They did not arise from the study area population's social and cultural changes. It was not a result of their immediate or future needs but rather the result of the economic changes. These results were developed to serve the visitors and arrivals to the city and achieve the highest financial profit.

Also, the absence of some descriptive indicators related to public, semi-public, and private spatial security does not eliminate the community's sense of security due to society's commitment to Islamic traditions and the planning structure on which the city was established.

Spatial empowerment indices did not reach an acceptable level, increasing the rates of purchase and rent of residential units and shops due to the rise in the land value, which led to unemployment. With the presence of a number of families that did not find adequate housing, it has had to search for adequate housing in other regions and neighborhoods. Therefore, the indices of empowerment require cooperation and concerted efforts of various parties, including the local government, the municipal council, the Urban Planning Directorate, and Civil society organizations, to improve all community groups' living conditions.

\section{Conclusions}

Sustainable development is based on spatial justice that achieves equal opportunities, creates equality, equity, and diversity in spatial distributions, and produces an efficient spatial structure capable of achieving the population's needs and improving their living conditions. Thus, the social and environmental aspects are positively affected. This study contributes to clarifying spatial justice and identifying the influential factors and indices in achieving it from a planning perspective.

This study found that there are five main factors for spatial justice, these factors are divided into ten applied indices. In practice, the indices can be used to identify deficiencies and evaluate development plans for the study area and other cities.

The indices reached in this study will provide planners and decision-makers with the required data about the imbalance of urban services' spatial distribution. They will help planners suggesting land uses and urban development strategies that reduce spatial inequality. Future research may pay more attention to studying how to achieve spatial justice in urban renewal projects and the relationship between urban form and spatial justice.

\section{References}

Achmani, Y., Vries, W. T. d., Serrano, J., \& Bonnefond, M. (2020). Determining Indicators Related to Land Management Interventions to Measure Spatial Inequalities in an Urban (Re) Development Process. Land, 9(11), 448.

Adli, S. N., Chowdhury, S., \& Shiftan, Y. (2019). Justice in public transport systems: A comparative study of Auckland, Brisbane, Perth and Vancouver. Cities, 90, 88-99.

Al-Jaberi, A., Al-Khafaji, A., Ivankina, N., \& Al-Sawafi, M. (2019). The idea of pedestrian pockets as a key for successful transit-oriented development for Najaf city-Republic of Iraq. Paper presented at the IOP Conference Series: Materials Science and Engineering.

Al-Khafaji, A., S., \& Al-Salam, N.,A. (2018). Measurment of Urban Sprawl and Compactness Characteristics, Nasiriyah CityIraq as Case Study. International Journal of Civil Engineering and Technology, Volume 9, Issue 9, $335-343$.

Al-Shouk, N. D., \& Al-Khfaji, A. S. (2018). Toward Sustainable Compact City:(Study in Convert Traditional Najaf City to Sustainable Compact City). KnE Engineering, 167-192-167-192.

Alrobaee, T., \& Al-Kinani, A. (2019). Place dependence as the physical environment role function in the place attachment. Paper presented at the IOP Conference Series: Materials Science and Engineering.

Alrobaee, T., Al-Khafaji, A., \& Al-Jawari, S. (2021). Measurement of physical environment characteristics for supporting transit-oriented development areas for the Kufa city -Iraq. International Journal of Scientific \& Engineering Research, 12( 1), 635-642.

Breheny, M. (1996). Centrists, decentrists and compromisers: views on the future of urban form. The compact city: A sustainable urban form, 13-35.

Burton, E. (2000). The compact city: just or just compact? A preliminary analysis. Urban studies, 37(11), 1969-2006. 
Colquhoun, I. (2004). Design out crime: Creating safe and sustainable communities. Crime prevention and community safety, $6(4), 57-70$.

Daniels, R., \& Mulley, C. (2013). Explaining walking distance to public transport: The dominance of public transport supply. Journal of Transport and Land Use, 6(2), 5-20.

Day, L. L. (2000). Choosing a house: the relationship between dwelling type, perception of privacy and residential satisfaction. Journal of Planning Education and Research, 19, 265-275

Delden, H. v., Hagen, A., Luja, P., Shi, Y.-e., \& van VLIET, J. (2008). Assessment and scenarios of land use change in Europe. Research published by RIKS BV, Netherland.

Dewan. (2011). Dewan architects and engineers. Urban Renewal of the City Centre of Holy Najaf: Comprehensive Master Plan of the City Centre of Holy Najaf. Ministry of Municipalities and Public Works, General Directorate of Physical Planning.

Fainstein, S. S. (2000). New directions in planning theory. Urban affairs review, 35(4), 451-478.

Fainstein, S. S. (2014). The just city. International journal of urban Sciences, 18(1), 1-18.

Feng, T., \& Timmermans, H. J. (2014). Trade-offs between mobility and equity maximization under environmental capacity constraints: A case study of an integrated multi-objective model. Transportation Research Part C: Emerging Technologies, 43, 267-279.

Force, T. U. T. (2003). Towards an urban renaissance: Routledge.

GHaedrahmati, S., Khademalhoosini, A., \& Tahmasebi, F. (2018). Spatial analysis of social justice in city of Isfahan, Iran. Annals of GIS, 24(1), 59-69.

Griffin, T. L. (2019). DESIGN FOR A JUST CITY: the Veldacademie, AIR and the Just City Lab, at Harvard Graduate School of Design (GSD).

Kay, A. (2005). Territorial justice and devolution. The British Journal of Politics and International Relations, 7(4), 544-560.

Mabin, A. (2013). Spatial justice as viewed from Gauteng, South Africa: professionals, planning, possibilities. Ségrégation et justice spatiale, 335-353.

Mahmoudi, S., Jelokhani-Niaraki, M., \& Argany, M. (2019). EVALUATION OF SPATIAL JUSTICE IN ACCESSIBILITY OF URBAN FACILITIES: A CASE STUDY OF ACCESSIBILITY OF PUBLIC PARKS IN DISTRICT\# 11 OF TEHRAN, IRAN. International Archives of the Photogrammetry, Remote Sensing \& Spatial Information Sciences.

Mecredy, G., Pickett, W., \& Janssen, I. (2011). Street connectivity is negatively associated with physical activity in Canadian youth. International journal of environmental research and public health, 8(8), 3333-3350.

Mirgholami, M., Keynejad, M. A., \& Alizadeh, B. (2018). The Evaluation of Spatial Justice in Redevelopment of Urban Spaces; Case study: Atigh Local Plan in the City of Tabriz. The Monthly Scientific Journal of Bagh-E Nazar, 15(67), 43-52.

Morrill, R. (2001). Spatial equity. International Encyclopedia of the Social \& Behavioral Sciences, 14789-14792. Elsevier

Nubani, L., \& Wineman, J. (2005). The role of space syntax in identifying the relationship between space and crime. Paper presented at the Proceedings of the 5th space syntax symposium on space syntax, delft, holland.

Owen, D. (2013). Future Identities: Changing identities in the UK-the next 10 years. Foresight.

Rafieian, M., \& Alizadeh, A. (2017). An Integrated Approach of Spatial Justice and Structure to Detect Spatial Conflicts in Yazd City. Iran University of Science \& Technology, 27(2), 105-114.

Uwayezu, E., \& De Vries, W. T. (2018). Indicators for Measuring Spatial Justice and Land Tenure Security for Poor and Low Income Urban Dwellers. Land, 7(3), 84. 